\title{
STANDING AS A BARRIER TO CONSTITUTIONAL JUSTICE - CAN WE CREATE A NEW ‘PUBLIC LAW PARADIGM’?
}

\author{
GeOFF HOLLAND*
}

This symposium provides us with an opportunity to re-assess how procedural rules impact on people who seek 'access to constitutional justice'. I understand the phrase 'access to constitutional justice' as meaning no more and no less than access to the courts to seek judicial review of the constitutional validity of laws. So who should have access?

In developing the general themes of this symposium and in Open Constitutional Courts, Patrick Keyzer has advanced new approaches to standing that, in the Australian constitutional context, challenge us to consider who may be excluded from access and why. Peter Johnston and Simon Evans point to the orthodox perspectives on standing and argue that Keyzer's suggestions may be regarded as radical when regard is had to orthodox accounts of contemporary Australian constitutionalism.

Keyzer has offered three distinct, although somewhat related, alternative arguments for a broader approach to standing. The first is that access to the courts for judicial determination of the constitutional validity of legislation is justified by the constitutionally implied freedom of communication on matters of political or governmental concern. ${ }^{1}$ The second is that the High Court has a duty to ensure constitutional limits are not infringed, this duty arising from the rule of law doctrine, and this gives rise to an 'entitlement' to know the constitutional validity of any law. Finally, Keyzer identifies popular sovereignty as a significant legitimising factor within the Australian constitutional context, and argues that the better view of the relationship between the people and the system of constitutional government reflected in that doctrine justifies and requires a more inclusive approach to standing.

The issue that I address today is whether these are viable alternatives to the present paradigm. In doing so I will focus on the first of Patrick Keyzer's hypotheses, and only touch on the second and third. However before doing this it is important to identify the problems with the contemporary law of standing that are carefully and persuasively explained by Keyzer in Open Constitutional Courts:

\footnotetext{
* Lecturer, Faculty of Law, University of Technology, Sydney, and Barrister.

1 As developed by the High Court under the leadership of Sir Anthony Mason.
} 
First, governments invoke standing rules to prevent would-be constitutional litigants with arguable cases from bringing their cases to court. That is, the case itself may be arguable, but standing rules allow governments to object to an action on the basis of who the litigant is, rather than what they are arguing. (This raises substantial and important questions about the capacity of Australian constitutional law to allow people to realise what their identity within Australian constitutionalism, a topic explored further in Open Constitutional Courts).

Second, the relator action does not provide a satisfactory alternative basis for access to constitutional justice.

Third, would-be constitutional litigants face crippling costs orders if they lose constitutional litigation, and this operates as a very serious disincentive to advancing a claim for constitutional justice (such orders can also be made in cases where standing provides the basis for rejecting a case).

There is broad consensus among Australian public lawyers that these problems with contemporary doctrines governing access to constitutional justice require solutions.

In Open Constitutional Courts, Keyzer persuasively argues that to address these problems it is necessary to reconceive Australian constitutionalism:

Constitutional law can and should accommodate the aspirations of all people in society as they can be reflected in constitutional law. Indeed, restricting access to constitutional justice contradicts the objectives of a system of government with a constitutionally entrenched guarantee of judicial review and freedom to discuss political and governmental affairs. Instead, the rules should be reformed to achieve access in a way that reflects the objectives of equal respect and equal dignity under the law. People and associations should be able to express their constitutional objections to government policy in the constitutional courts. This will enhance the adjudicative legitimacy of Australian constitutional courts.

The High Court's approach to standing in public law matters in Australia, like the US Supreme Court, has been shaped by common law traditions, with a need to show some harm or damage arising from the purported constitutional violation. Richard S Kay has termed this 'Injury-Standing'.2 Kay identified another approach, one in which 'the main purpose is to clarify the meaning of constitutional rules so as to facilitate their observance' and is intended to perfect the operation of the constitutional system as a whole rather than benefit any particular individual. ${ }^{3}$ The term 'Inquiry-Standing' was

2 Richard S Kay (ed), Standing to Raise Constitutional Issues: Comparative Perspectives (Bruylant, 2005).

3 Ibid 2. It should not be overlooked that in Attorney-General (Vic); Ex rel Black $v$ The Commonwealth (the Defence of Government Schools case) (1981) 146 CLR 559, 634, Murphy J 
adopted to describe this broader approach to standing ${ }^{4}$ and it is here that Keyzer's theories can be located.

\section{Can access to the courts be a form of communication?}

Patrick Keyzer argues that an application for judicial review can be characterised as a form of anti-government expression and as such comes within the implied freedom of communication. ${ }^{5} \mathrm{He}$ then applies the 'Lange test' to determine whether those rules are compatible with the implied freedom of communication, and argues persuasively that common law rules governing standing are inconsistent with that test. Simon Evans has identified a number of distinct problems with this line of reasoning. I propose to address some of them.

Arguing that judicial review has both an expressive aspect (the making of the application) and a performative aspect (the legal proceedings), Evans reasons that the implied freedom only protects expressive aspects of communication. However, if the freedom is seen as placing an emphasis on the maintenance of public debate in which 'all viewpoints are fully and fairly heard', as suggested by Michael Chesterman, ${ }^{6}$ it is a freedom to both speak and hear, including hearing the Court's answers to questions on the constitutional validity of laws. Whilst the making of an application for judicial review may be expressive conduct it is not unreasonable, nor inconsistent with the ways in which the High Court has approached the implication, to argue that the process of judicial review (where the outcome is the answering of a question of constitutional validity) is part of the communication protected by the freedom. It is a novel argument (Evans prefers the expression 'radical'), but Keyzer's argument is a very good argument, and has solid constitutional foundations.

Simon Evans also argues that there is no indication that ss 75 and 76 of the Constitution should yield to an implication arising from ss 7, 24 and 128. But if it is accepted that the people, as recognised by the Constitution, would, in determining their voting intentions, have a real interest in knowing whether governments are

observed that '[a]ny one of the people of the Commonwealth has the standing to proceed in the courts to secure the observance of constitutional guarantees'.

4 Ibid.

5 Patrick Keyzer, Open Constitutional Courts, (Federation Press, 2010), Chapter 6. This is an application of the Lange test as modified in Coleman v Power (2004) 220 CLR 1, 50-3, 77-8, 82. I am indebted to Patrick Keyzer for an advance copy of this book.

6 Michael Chesterman, Freedom of Speech in Australian Law - A delicate plant (Ashgate, 2000) 39-40. It is suggested that the reasoning of the High Court in Lange v Australian Broadcasting Corporation (1997) 189 CLR 520 is supportive of a 'deliberative' notion of the freedom of communication in which the interests of both potential speakers and their audience are acknowledged. 
acting within the limits of constitutional boundaries (bringing it within the scope of a communication concerning matters of political or governmental concern) the issue is one of whether the law of standing is reasonably appropriate and adapted to achieve a legitimate constitutional purpose. If, as Evans argues the standing rules achieve a purpose beyond merely protecting the courts from baseless actions, the question that Keyzer has raised remains: do the current rules go beyond that which is required to allow for the proper functioning of the court, including restricting access? After all, as Keyzer points out, the system of representative government ordained by the Constitution does not operate extraneously to judicial review, but is an integral part of that system; they are parts of a single system. Ultimately Evans does not address this important question. 